\title{
Foreign Shares, Human Capital and Wage Inequality: Evidence from Indian Manufacturing Firms
}

\author{
Gunja Baranwal \\ Centre for Studies in Social Sciences, Calcutta, India \\ Email: baranwalgunja@gmail.com
}

How to cite this paper: Baranwal, G. (2017) Foreign Shares, Human Capital and Wage Inequality: Evidence from Indian Manufacturing Firms. Modern Economy, 8, 1150-1166.

https://doi.org/10.4236/me.2017.89080

Received: January 31, 2017

Accepted: September 25, 2017

Published: September 28, 2017

Copyright $\odot 2017$ by author and Scientific Research Publishing Inc. This work is licensed under the Creative Commons Attribution International License (CC BY 4.0).

http://creativecommons.org/licenses/by/4.0/

\begin{abstract}
The interactions between Foreign Direct Investment (FDI) and human capital formations have strong implications for labour demand and supply factors in developing economies through various ways like training, direct technological diffusion, innovation and imitation. Indian economy has featured rising wage inequality and demographic dividend simultaneously since the last decade. In line with the similar research, the objective of the paper is to empirically assess this effect in Indian manufacturing firms using unbalanced panel data for the period 2001-2015. This paper uses fixed effects panel data estimation technique to get the estimates. The findings reflect that FDI is found out to be stirring up wage inequality with positive relation between relative wages and interaction term of training and FDI suggestive of positive demand side effect of FDI only through this channel.
\end{abstract}

\section{Keywords}

Foreign Direct Investment, Human Capital, Labour Demand, Labour Supply, Wages

\section{Introduction}

Inquiry into the growth drivers of countries has always been a major issue of research. Over the period of time these drivers have changed. Trade, Foreign Direct Investment ${ }^{1}$ (FDI) and human capital have emerged as the new factors causing growth of economies. Free capital mobility among the countries led to advent of Multinational Enterprises (MNE's) ${ }^{2}$, thus providing a substitute to ${ }^{1}$ Foreign Direct Investment is the Greenfield investment by some foreign national company to some other foreign host country for the purpose of production and sale. It can come under either automatic route or government route. Different sectors have different limits for FDI in India which keeps changing for with policies and time.

${ }^{2}$ I use the terms Foreign Direct Investment and Multinational Enterprises interchangeably henceforth. 
domestic investment. This FDI has the potential to affect the host country's macroeconomic variables like growth, income, investment and employment [1]. FDI directly ameliorates production through better technologies, financial capabilities, and provision of state of the art. It affects level of domestic investment via crowding in and crowding out effect. The indirect effects of FDI include spill-over effects [2] [3]. [4] find foreign entry through acquisition affects positively domestic firm's productivity. [5] discuss the effect of research and development expense of foreign firms in domestic market. Similarly human capital also has significant long run impact on an economy's income and employment. Human capital formation takes place through on the job training, schooling, and other knowledge gained through experience and learning by labour force [6]. Investments in human capital affect wages. This stock of human capital determines the technological absorptive capacity of country [7]. Human capital creates positive spillovers to economy [8]. The research suggests that these spillover effects from human capital boost the economy through the indirect channel by increasing the quantity and the quality of labour force in economy. FDI also affects the labour market through changes in employment and wage structure of labour force [9] [10] [11]. It may increase the wages in host country. It may lead to human capital formation through upgrading the skills of human capital of host countries by provision of formal training, schooling and spill-over effects of layoffs and turn overs of labour force from international firm to domestic firms [12] [13] [14]. FDI affects the local level of research and development by creating positive spillovers. Thus these may be considered supply side effects of FDI on human capital formation process of the host country. On the supply side, FDI may affect the human capital formation in terms of skill up-gradation of labour force, thus contribute to supply of human capital. However in the process, FDI also demands specific kind of human capital thus also affects the wages of different categories; highly skilled, mid skilled and low skilled of human capital [15] [16]. Both of these effects are crucial as they have long term consequences on labour force of host economy. The significance of either effect is important in determining the overall effect of FDI in a country. This is the first attempt to assess this effect empirically in Indian manufacturing industries for the last decade. The structure of the paper is organised as followed: In Section 2, I discuss trends of FDI, human capital formation and wage inequality in India. In Section 3, I discuss the theoretical framework. Empirical strategy has been developed in Section 4. Data has been discussed in Section 5. In Section 6, I discuss our variables formation. Section 7 presents the results of effect of FDI on human capital formation and relative wages. I also check for high technology and low technology industries in this section. Section 8 concludes the discussion.

\section{Trends of FDI and Human Capital Formation, Wage Inequality in India}

\subsection{Trends of FDI}

India remains the third most attractive destination for FDI, after China and the 
United States of America, for 2013-15, according to a survey of global companies conducted by UNCTAD. Foreign Direct Investment in India has increased from $\$ 104,411$ in year $2000-2001$ to $\$ 696,011$ in 2011-2012. The distribution of FDI inflow is concentrated to some sectors. Services, Construction, Communication, Drugs and Pharmaceuticals, Chemicals, Automobile Industry etc. are among the leading sectors which bag major share of FDI inflows. Similarly there is spatial clustering in spread of FDI as some economically advanced regions have accounted for the lion's share of FDI inflows. Top of them are states of Maharashtra, Delhi, Tamilnadu, Karnataka, Gujarat and Andhra Pradesh. Whereas states like Uttar Pradesh, Madhya Pradesh, Bihar, Orissa, Rajasthan and North-eastern region managed to receive no or only a meagre amount of FDI inflows. In literature there are several determinants responsible for this clustering like availability of quality labour force, size and growth of local markets, physical infrastructure, policy environment, business climate, and presence of agglomeration economies [17] [18].

\subsection{Human Capital Base in India}

Human capital base is on rise in India over the past decades. Government has come up with various policies across different layers of education system for example at primary, secondary and tertiary level there are many on -going polices in education sector. Besides that there has been increase in income level in country which has made the education more accessible resulting higher human capital base. For example: Gross enrolment ratio in tertiary education of India has increased with compound annual growth rate of 7.8\% during 2001-2002 to 2007-2008 (Figure 3). ${ }^{3}$ Similar trend is observed in spread of higher education clustered in southern states of Tamilnadu, Karnataka, Andhra Pradesh, Kerala but northern states like Bihar, Orissa, Uttar Pradesh, Madhya Pradesh being laggards. The composition of human capital is concentrated to some special courses with replacement of professional courses with general courses (Figure 4). Similarly National Skill Development Corporation based on public-private partnership, of government of India has also been engaged in funding and incentivizing vocational training initiatives for skill development via training partners and sectoral skill councils. It has 187 training partners, 2228 training centers. It boasts of having trained 3,366,647 people and 1,473,647 people placed.

\subsection{Wage inequality in India}

Wage inequality both on average and based on skills has seen an upwards trend since last decade. Indian wage inequality has been vastly studied (Figures 1-4). [19].

\section{Theoretical Framework}

The paper follows modification of [20] [21] to analyse the effects of FDI on relative wages. It can be represented by two factor CES production function with low skilled labour (U) and high skilled labour (S) as two inputs.

${ }^{3}$ Human Resource Development report, 2011. 
Cumulative Total FDI (from January 2000 to July, 2013) In U.S.\$

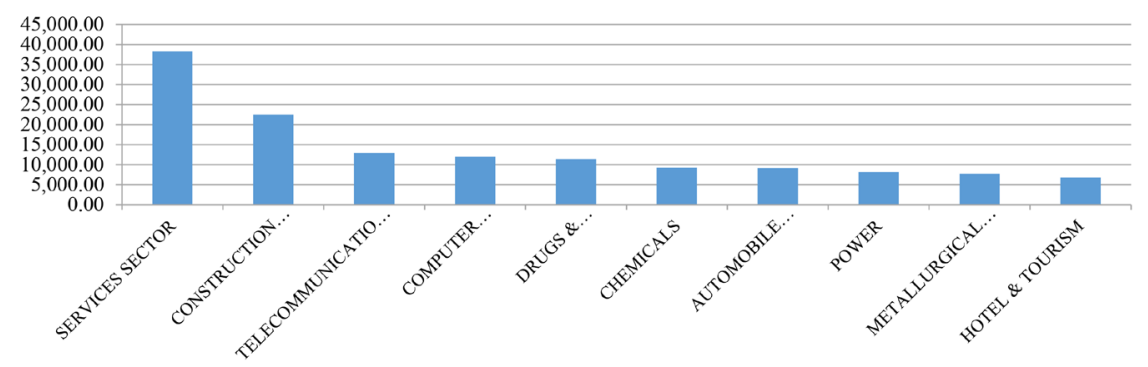

Figure 1. Sectoral clustering of FDI in India. Source: SIA newsletters, DIPP, India.

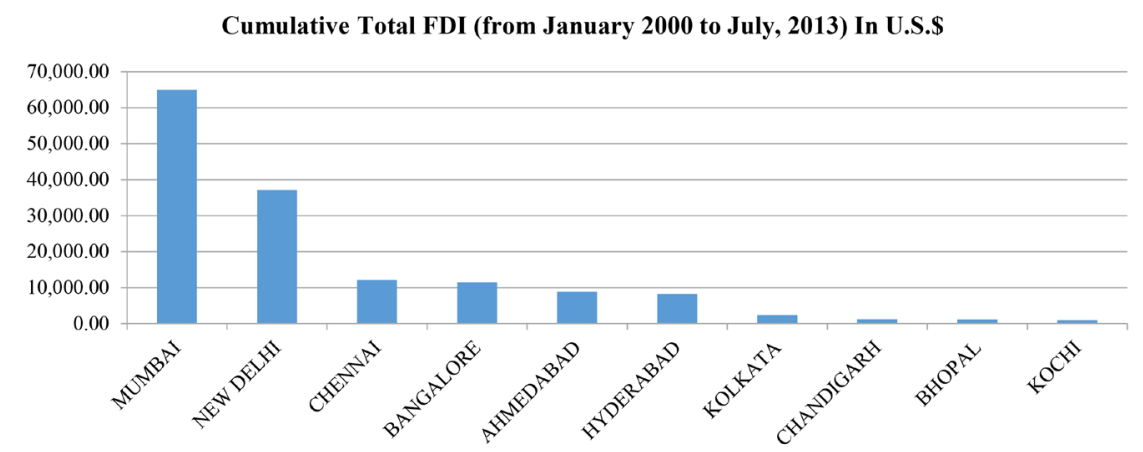

Figure 2. Spatial clustering of FDI in India. Source: SIA newsletters, DIPP, India.

total higher education institutes

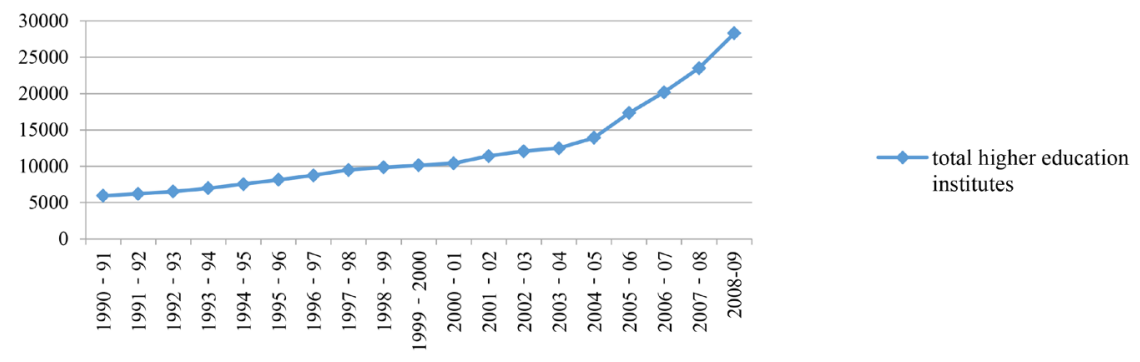

Figure 3. Human capital formation in India over the years. Source: All India Survey on Higher education, ministry of HRD, India.

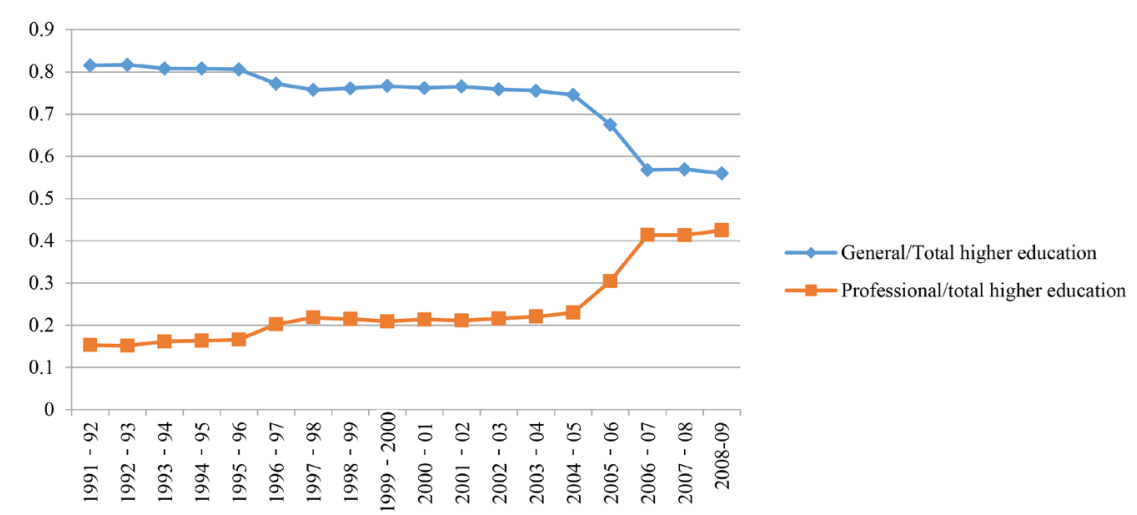

Concentration of educational institutes in India

Figure 4. Clustering of human capital (higher education) in India. Source: All India Survey on Higher education, ministry of HRD, India [32]. 


$$
\begin{gathered}
f\left(U_{t}, S_{t}\right)=\left\{\lambda\left(\psi_{U t} U_{t}\right)^{\rho}+(1-\lambda)\left(\psi_{S t} S_{t}\right)^{\rho}\right\}^{\frac{1}{\rho}} \rho<1 \\
\varphi_{U t} \equiv \ln \psi_{U t} ; \varphi_{U t}=\gamma_{1 U} t+\gamma_{2 U} F S ; \varphi_{S t} \equiv \ln \psi_{S t} ; \varphi_{S t}=\gamma_{1 S} t+\gamma_{2 S} F S
\end{gathered}
$$

where $\varphi_{U t} \equiv \ln \psi_{U t}$ and $\varphi_{S t} \equiv \ln \psi_{S t}$ are functions of labor efficiency units, parameter $\rho<1$. Labor efficiency index can be interpreted as accumulated human capital. The elasticity of substitution between $U$ and is $S \sigma=1 / 1-\rho$. The possible changes in technology may come through factors like FDI, openness and interaction terms of foreign investment with firm level characteristics. These are some routes through which FDI can affect labour market. These demand shift factors are factors like foreign direct investment and international trade. ${ }^{4}$ Thus this labour efficiency indices is a function of share of foreign promoters in equity shares FS, interaction terms $F S_{i t} * \operatorname{train}_{i t}, F S_{i t} *$ royal $_{i t}, F S_{i t} * R n D_{i t}, F S_{i t} * K L_{i t}$ and host of firm level factors as training expenses, royalty expenses, research and development expenses, capital labour ratio, size etc. ${ }^{5}$ In order to assess the human capital formation process done by foreign firms, I test other interactions terms of FDI and training expenses of the firms and royalty.

Solving for first order condition and keeping marginal productivity equal to factor prices, $I$ derive the formula for relative wages of skilled-unskilled labor.

$$
\ln \left(\frac{w_{S t}}{w_{U t}}\right)=\ln \left(\frac{1-\lambda}{\lambda}\right)-\frac{1}{\sigma} \ln \left(\frac{S_{t}}{U_{t}}\right)+\frac{\sigma-1}{\sigma} \gamma_{1} F S_{t}+\varepsilon_{t}
$$

where $\gamma_{1}=\gamma_{1 S}+\gamma_{1 U}$ and $\gamma_{2}=\gamma_{2 S}+\gamma_{2 U}$ thus wage inequality depends on a supply term (relative supply of high to low skilled labor and FDI (foreign shares). The sign of $\gamma_{1}$ directs the effect of FDI on wage inequality. A positive $\gamma_{1}$ tends to increase wage inequality.

\section{Econometric Estimation}

My basic equation is of demand and supply kind. Empirical estimation of this equation requires use of simultaneous equation method due the existence of possible endogeneity in the system. Thus the dependent variable should be relative wages and main the independent variable, relative employment along with all the demand shift factors and controls. The equation would represent the changes in relative wages of skilled and unskilled labour force being explained by differences in skill and unskilled labour force equation and it should look like Equation (4).

$$
\begin{aligned}
\ln \{r l w\}_{i t}= & \alpha_{i}+\beta_{1} \ln \left\{\text { rlemp }_{i t}+\beta_{2} F S_{i t}+\beta_{3} O I_{i t}+\beta_{4} \text { train }_{i t}+\beta_{5} R n D_{i t}\right. \\
& +\beta_{6} \text { royal }_{i t}+\beta_{7} K / L_{i t}+\beta_{8} F S_{i t} * \text { train }_{i t}+\beta_{9} F S_{i t} * K / L_{i t} \\
& +\beta_{10} F S_{i t} * \text { roy }_{i t}+\beta_{11} F S_{i t} * R n D_{i t}+\beta_{12} \text { size }_{i t}+\beta_{13} \text { size }_{i t}^{2}+\varepsilon_{i t}
\end{aligned}
$$

But it actually does not solve the purpose since the goal is to see the effect of foreign direct investment on human capital formation, not to identify the supply

${ }^{4}$ The effect of foreign direct investment on wage inequality is well researched in literature [15] [19] [22].

${ }^{5}$ This also makes us drop the log specification since I are not interested in estimating elasticity of substitution between skilled and unskilled labour. 
and demand curves, $I$ can safely drop relative employment from Equation (4). In other words it also implies that $I$ am are interested in the shifts in relative labour demand caused by foreign direct investment Figure 5(a) rather than identifying demand and supply curve. In latter case there is a condition of multiple equilibria Figure 5(b). To this end, our equation boils down to Equation (5). I estimate our final equation ${ }^{6}$ :

$$
\begin{aligned}
\left\{\text { rlw }_{i t}=\right. & \alpha_{i}+\beta_{1} F S_{i t}+\beta_{2} O I_{i t}+\beta_{3} \text { train }_{i t}+\beta_{4} R n D_{i t}+\beta_{5} \text { royal }_{i t}+\beta_{6} K / L_{i t} \\
& +\beta_{7} F S_{i t} * \operatorname{train}_{i t}+\beta_{8} F S_{i t} * K / L_{i t}+\beta_{9} F S_{i t} * \text { roy }_{i t}+\beta_{10} F S_{i t} * R n D_{i t} \\
& +\beta_{11} \text { size }_{i t}+\beta_{12} \text { size }_{i t}^{2}+\varepsilon_{i t}
\end{aligned}
$$

So now I implicitly assume relative employment is given exogenously and I am are estimating the shifts in demand side of labour market explained by other factors like FDI, openness firm specific factors and their interaction terms. Thus the main hypothesis of the paper will be to find out if parameters $\beta_{1}, \beta_{2}, \beta_{3}$, $\beta_{4}, \beta_{5}, \beta_{6}, \beta_{7}, \beta_{8}, \beta_{9}, \beta_{10}, \beta_{11}, \beta_{12}$ are statistically significant or not. Where $\beta_{1}$ and $\beta_{2}$ show the effect of foreign share and openness, $\beta_{3}, \beta_{4}$, $\beta_{5}, \beta_{6}$ show the effect of human capital indicators and $\beta_{7}, \beta_{8}, \beta_{9}, \beta_{10}$ show the effect of the interaction term of FDI and human capital indicators. Lastly $\beta_{11}, \beta_{12}$ capture the size effect in the equation.

\section{Data}

Paucity of skill based firm level employer-employee data in India poses a strong challenge in testing our hypothesis. This leaves us with the alternative to create relative indices with all possible data available. I use CMIE database to test our hypothesis. CMIE provides data on listed Indian firms based on their income statements and balance sheets. Prowess ${ }^{7}$ database is based on publicly available information on financial condition of Indian companies which range from listed large and medium public limited, private and cooperative companies. This is the only source of micro data on Indian firms which gives minute details of income, expenses, structure and other resources of the firms. This is the virtue of PROWESS data in comparison with ASI (Annual Survey of Industries) data which does not give plant level information of Indian industries on such distinct aspects. The empirical exercise has been conducted using Prowess database published by Centre for Monitoring Indian Economy for the period from 2001-2015 for NIC two digit non-financial public and private limited manufacturing firms trading on National Stock Exchange and Bombay Stock Exchange. The industries included are Food (104), Metal and Metal products (115), Textile (97),

${ }^{6}$ This also makes us drop the log specification since I are not interested in estimating elasticity of substitution between skilled and unskilled labour.

${ }^{7}$ The Prowess database is packaged into a software. This software and the database are installed on the user's computer. The software enables database access, presentation of tabulations, plotting of charts and updation of the database. Prowess is designed to help users access information for individual companies. There are tools to search companies in the database that match search-criteria provided by users. Prowess presents several tabulations (such as financial statements) and charts (including those of share prices). These presentations help the user in quickly analysing the companies in the database. (https://prowessiq.cmie.com/). 


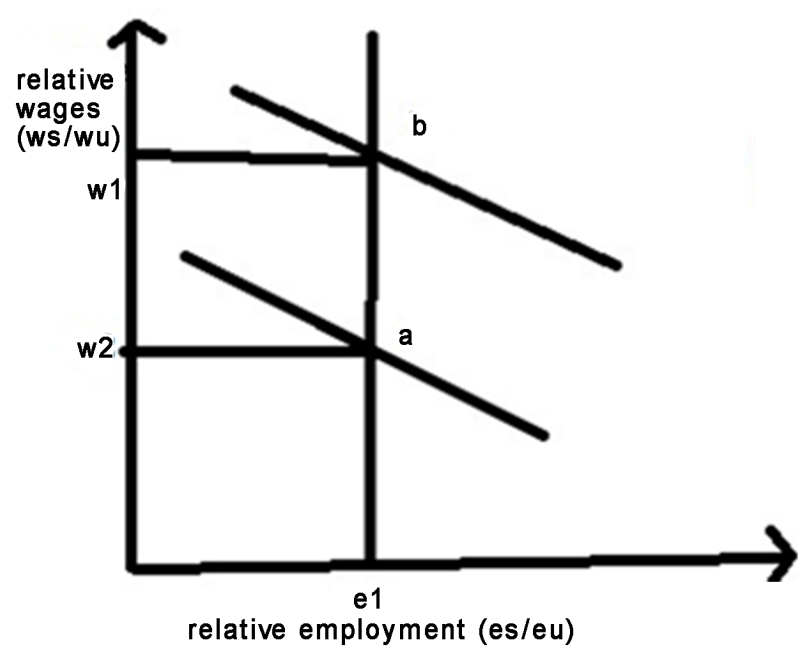

(a)

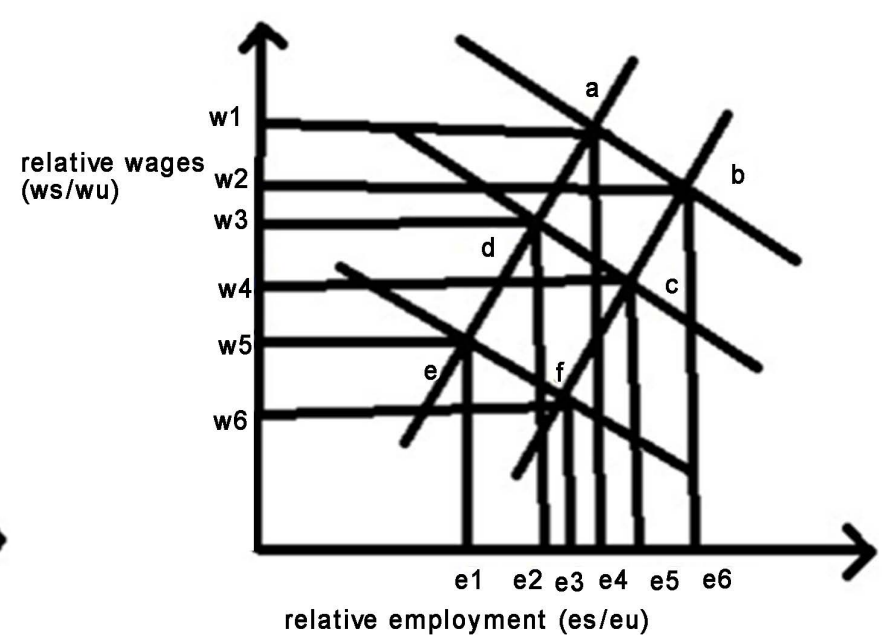

(b)

Figure 5. Identification problem of demand and supply curve.

Chemicals (274) and Consumer goods (63), Construction (69), Machinery (151) and Transport Equipment (95). The result is an unbalanced sample of 1023 firms as our final sample.

\subsection{FDI policy and Indian Manufacturing Sector}

\subsubsection{FDI Policy and Indian Industries}

Food processing industry accounts for $9 \%$ share of manufacturing GDP with average annual growth rate of $8.4 \%$. FDI is allowed $100 \%$ of under automatic route except for items reserved under Micro, Medium and Small enterprises where FDI limit is $24 \%$ through automatic route. The structure of demand for food has changed in Indian with a shift towards more processed form with changed consumer preferences. The government has implemented different schemes to boost FDI in this sector like establishing Mega Food Parks and Agri-Export Zones. ${ }^{8}$ Textile industry contributes $14 \%$ of industrial output and $4 \%$ of the total GDP in India. "The country attracted $\$ 198.86$ million foreign capital in the sector during April-March 2013-14, up 91.41 percent”, says Business Standard, August, 15,2014 . Textile industry also allows for $100 \%$ FDI under automatic route. ${ }^{9}$ The government has come up with Technology Up gradation Fund Scheme, Integrated Textile Parks, Integrated Processing Schemes and Integrated Skill Development Scheme. Chemical sector contributes 16\% of manufacturing GDP and $2.11 \%$ of Indian GDP. This sector has estimated size of the market USD 144 billion and covers 70,000 commercial products. This sector also allows 100\% FDI under automatic route besides a few restrictions on industries registered under MSME sector. Strong domestic and export demand have caused growth of the sector. The government has begun policy to setup Petroleum, Chemicals and

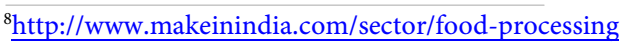

${ }^{9}$ http://www.makeinindia.com/web/mii/sector/textiles-and-garments, http://www.ibef.org/industry/textiles.aspx 
Petrochemicals Investment Regions (PCPIR) which is an investment region spread across 250 square kilometres with basic infrastructure for the manufacture of domestic and export related products of chemicals, petroleum and petrochemicals. ${ }^{10}$ Consumer goods industry has grown with compound annual growth rate of $10.8 \%$ for the period $2003-2012$. With $65 \%$ of urban market the industry, it allows $100 \%$ of FDI in single brand retail and $50 \%$ in multi-brand retail industry. ${ }^{11}$ Crude steel production has increased at CAGR of $8.2 \%$ between 2008-2011 producing 76.7 million metric tons. Government has allowed 100\% of FDI under automatic route in exploration, metallurgy for non-fuel and non-atomic minerals. The government is providing assistance for Steel Development Fund and Special Economic Zones for promoting the development of this sector. ${ }^{12}$

\section{Variables Formation}

Labour demand is proxied by the relative changes in wages. Thus, our dependent variable is relative price of labour. It is the ratio of skilled to unskilled labour in a firm. I derive this indicator by dividing wages and salaries paid by firms in prowess data base to the average wages of rural sector ${ }^{13}$ for men over the years at all India level provided by Labour Bureau. This creates our index of relative labour prices that I use for relative labour demand changes. Many studies have attempted to find out the impact of FDI on development process of countries. The results are very different for developed and developing countries. I try to assess the impact of FDI on relative wage ratio of skilled and unskilled labour. I measure it by share of foreign equity in annual equity shares of firms. Some studies use binary measure of private and foreign ownership at the expense of information. But the relation between foreign ownership is better approximated as linear than binary. Openness is the frequently used indicator in literature to explain effect of international exposure of firms on wage inequality [19]. My openness indicator is constituted by the ratio of sum total forex earnings, total forex spending by the total income of the firms. Openness may lead to increase in demand for skilled labour force in case of skill intensive exports. I use four indicators of human capital which may directly or indirectly lead to skill up-gradation. On the job training provided increases the supply of skilled labour force and therefore should affect the level of wages in economy by increasing the productivity and bargaining power of labour [6] [23]. The measure of training is annual expenses financed by firms on training their employees which upgrades the level of skills. It has been normalised by dividing it by sales of firms. It is an endogenous tool of innovation in new growth theory. Firms invest for accumulation of

\footnotetext{
${ }^{10} \mathrm{http} / / /$ www.makeinindia.com/sector/chemicals/

${ }^{11} \mathrm{http}: / /$ www.ibef.org/industry/indian-consumer-market.aspx

${ }^{12}$ http://www.makeinindia.com/sector/mining/, https://www.ibef.org/industry/steel.aspx

${ }^{13}$ Rural sector includes activities like ploughing, sowing, weeding ,transplanting, harvesting, winnowing, threshing, picking, herdsmen, well digging, cane crushing, carpenter, blacksmith, cobbler, mason, tractor driver, sweeper and unskilled labourers. Labour Bureau.
} 
knowledge capital. This accumulation of knowledge capital increases the productivity, wages and thus sharpens the skills of labour force. I use annual investment by the firms in research and development activities normalised by sales of firms. Imitation is another indirect form of human capital formation coming through adoption of technologies. Along with $\mathrm{RnD}$ activities firms also invest in purchasing already patented technologies. It increases the skill level indirectly by imitation of technologies. The indicator of royalty payment is expenses by firms on royalty payments normalised by sales of the firms. This is also an indirect indicator for human capital formation which works through technological changes. Multi-national enterprises encourage technological up-gradation for domestic firms. I create our capital-labour ratio by dividing gross fixed assets by number of employees in the firm. Capital-skill complementarity increases the demand for skilled labour and therefore increases wage inequality between skilled and unskilled. In order to separate the role of foreign firms on human capital formation from domestic, I use four interaction terms. These terms show the effect of foreign firms on human capital formation. This indicator looks at the direct effect of foreign firms on human capital formation and skill up gradation of employees by imparting them training. It is product of annual foreign share and training expenses by the firms. It affects the wages directly by increasing productivity and bargaining power of labour force. It shows the innovation practices made by the foreign firms in India. Theses foreign innovation practices lead to skill up gradation. It is a product of foreign share and research and development expenses by firms [2]. [24] find positive effect of research and development expenses by foreign firms on total factor productivity. Foreign firms also spend on purchasing technologies to imitate them. This variable reflects the indirect effect of imitation of technology on wages of labour. Foreign share and royalty payment make up this variable. Another indicator of technological change brought about by the foreign firms is a product of foreign share and capital-labour ratio of the firms. It shows the direct effect of foreign technology on wage inequality. I take the size of firms in all the specifications in order to control for the firm specific characteristics. It is the total annual sales of the firms. Larger firms give higher packages to their employees. Size ${ }^{2}$ term is included to account for the non-linarites' in firm specific indicators. It is a square term of size of firms. It represents that as the size of the firm increases the size of packages they offer to their employees declines.

\section{Estimation Results}

My panel includes missing values on some of the variables (Appendix) which actually leads to reduce the sample size (Table 1). Another problem caused by systematic missing data is that it may produce the selection bias. But in case of missing data completely at random also termed as Missing Completely At Random (MCAR), any value of an observation neither depends on its own value nor on values of other variables in the set [25] [26]. It does not produce biases 
Table 1. Description of variables.

\begin{tabular}{|c|c|}
\hline Variable Description of Variables & Signs \\
\hline$\{r l w\}_{i t}=\left\{\frac{W_{\text {Sit }}}{W_{\text {Uit }}}\right\}$, relative price of labor, ratio of skilled to unskilled labor force in firms & \\
\hline$F S_{i t}=$ equity share of foreign promoters in firms & $(+)$ \\
\hline $\begin{array}{l}O I_{i t}=\text { Total forex earnings }+ \text { Total forex spending/Total Income }, \text { Openness Index of } \\
\text { firms }\end{array}$ & $(-)$ \\
\hline$K / L_{i t}=$ Gross Fixed assets/number of employees of firms & $(+)$ \\
\hline train $_{i t}=$ training expenses by firms on their employees & $(-)$ \\
\hline royal $_{i t}=$ royality expenses by firms & $(-)$ \\
\hline$R n D_{i t}=$ Research and Development expenses by the firms & $(-)$ \\
\hline \multicolumn{2}{|l|}{ Interaction terms } \\
\hline$F S_{i t} * \operatorname{train}_{i t}=$ Interaction Term 1, FS $*$ Training expenses by firms & $(-)$ \\
\hline$F S_{i t} * K / L_{i t}=$ Interaction Term 2, $F S *$ Capital - Labor ratio of firms. & $(-)$ \\
\hline$F S_{i t} *$ roy $_{i t}=$ Interaction Term 3, FS $*$ Royality expenses by firms & $(-)$ \\
\hline$F S_{i t} * F S_{i t}=$ Interaction Term 4, FS * Research and Development expenses & $(-)$ \\
\hline size $_{i t}=$ sales of firms & $(+)$ \\
\hline $\operatorname{size}_{i t}^{2}=\operatorname{size}_{i t} * \operatorname{size}_{i t}$ of firms & $(-)$ \\
\hline
\end{tabular}

though it may have less precision. Since these missing values are randomly missing, they do not affect our results of estimation and I also take robust standard errors to minimise the possibility of less precision. ${ }^{14}$ I start with estimating my baseline equation where I look at the effect of foreign shares and openness indicator of the firm while also controlling for firm level variables. Then the empirical strategy extends to include the human capital indicators one by one to see the effects of all of them on relative wages. One way of finding out the human capital formation effect of foreign shares is to incorporate the interaction term of foreign share and expenses done by firms on human capital formation through different channels.

Table 2 shows the results for the baseline equation through Ordinary Least Squares method and Fixed Effects estimation method. Column (1) finds out the positive and significant impact of openness of the firms on relative wages. Whereas the impact of foreign shares on relative wages is negative in ordinary least squares estimation suggesting a reduction in wages inequality caused by the foreign ownership shares. On the job training which is considered to be increasing the bargaining power of the workers and thereby their salaries, comes out to be negative. The interaction term of foreign share and training has a significant and positive impact on relative wages. The problem with OLS estimation is that it does not account for the firm level effects which may cause the biased estimates in Column 2. Thus I estimate the same model with fixed effects which ${ }^{14}$ Other studies using PROWESS database also faced this problem due to unbalance panel, but it does not affect their results [27] [28] [29]. 
Table 2. Effect of FDI on relative wages. (Baseline model).

\begin{tabular}{ccc}
\hline Explanatory vars & OLS (1) & Fixed Effects (2) \\
\hline \multirow{2}{*}{ Foreign shares } & $-0.01^{* * *}$ & -0.002 \\
& $(0.004)$ & $(0.003)$ \\
Openness & $0.002^{\star *}$ & $0.0001^{* *}$ \\
& $(0.0003)$ & $(0.0002)$ \\
training & $-3.31^{* *}$ & $3.28^{* * *}$ \\
& $(1.03)$ & $(0.32)$ \\
fditrain & $0.001^{* * *}$ & $0.0004^{* * *}$ \\
& $(0.00001)$ & $(0.0001)$ \\
size & $0.0001^{\star * *}$ & 0.0001 \\
& $(0.00002)$ & $(0.0001)$ \\
Size square & $9.08 \mathrm{e}-12$ & $9.68 \mathrm{e}-11$ \\
& $(7.23 \mathrm{e}-11)$ & $(3.23 \mathrm{e}-10)$ \\
F value & $497.50^{* * *}$ & - \\
$\mathrm{R}^{2}$ & 0.70 & 0.64 \\
Observations & 1248 & 1248
\end{tabular}

takes care of firm level effects in panel data models. Foreign share becomes insignificant with no changes in the sign whereas training now becomes positive. The effects of openness and interaction term still remain positive and significant.

In Table 3, I extend the analysis by incorporating my full model in which I look for all the channels through which foreign shares may affect wage inequality in domestic firms. I test for effect of on the job training, research and development expenses, capital labour ratio and royalty expenses on relative wages separately. The reasoning is, a positive relation between relative wages and interaction term of foreign share and human capital implies supply of skills by foreign firms, is lesser than the demand for skills which is denoted by relative wages of skilled to unskilled labourers. The result is disequilibrium in skills market and increased wage inequality. The first column shows the results for training expenses on relative wages. The coefficient of training is positive and significant which actually reflects that as the employees become skilled they will also become eligible to enter into a higher income band due to increased bargaining power. The coefficient of the interaction term is positive and significant which may imply that these foreign firms are actually leading to wage inequality through provision of training to their employees (Table 3 Column 1). Next I test for the innovation channel Column 2 shows the results for effects of research and development expenses and its interaction term with foreign share on relative wage inequality. Research and development expenses by foreign firms are not found to affect relative wages. Similarly the coefficient of $\mathrm{RnD}$ and foreign shares is negative but not significant. Thus I cannot conclude anything about this channel of effect. Column (3) shows the results for the indicator for technological change. The coefficient of capital labour ratio is found to be insignificant and positive whereas the coefficient of interaction term of capital labour ratio and foreign shares is as well insignificant. The result of the channel of royalty is 
Table 3. Effect of FDI and openness on relative wages (baseline model).

\begin{tabular}{|c|c|c|c|c|}
\hline Explanatory vars & $\begin{array}{l}\text { On-the-job } \\
\text { training } \\
\text { (1) }\end{array}$ & $\begin{array}{l}\text { Research and } \\
\text { development } \\
\text { (2) }\end{array}$ & $\begin{array}{c}\text { Capital labour } \\
\text { ratio } \\
(3)\end{array}$ & $\begin{array}{c}\text { Royalty } \\
\text { (4) }\end{array}$ \\
\hline Foreign shares & $\begin{array}{c}0.009 \\
(0.008)\end{array}$ & $\begin{array}{c}0.001 \\
(0.009)\end{array}$ & $\begin{array}{l}0.21^{* *} \\
(0.02)\end{array}$ & $\begin{array}{l}0.004 \\
(0.01)\end{array}$ \\
\hline $\begin{array}{l}\text { Openness } \\
\text { training }\end{array}$ & $\begin{array}{c}0.0001 \\
(0.0002) \\
1.52 \\
(1.93)\end{array}$ & $\begin{array}{c}0.0005^{\star} \\
(0.0002) \\
-\end{array}$ & $\begin{array}{c}0.0007^{\star *} \\
(0.0002) \\
-\end{array}$ & $\begin{array}{c}0.0002^{\star *} \\
(0.00001) \\
-\end{array}$ \\
\hline fditrain & $\begin{array}{l}0.0001^{\star *} \\
(0.00007)\end{array}$ & - & - & - \\
\hline$R n D$ & - & $\begin{array}{c}6.57 \\
(10.12)\end{array}$ & - & - \\
\hline fdirnd & - & $\begin{array}{l}-0.11 \\
(0.29)\end{array}$ & - & - \\
\hline$k l$ & - & - & $\begin{array}{l}0.0002 \\
(0.003)\end{array}$ & - \\
\hline fdikl & - & - & $\begin{array}{c}-5.64 \mathrm{e}-06 \\
(0.00004)\end{array}$ & - \\
\hline roy & - & - & - & $\begin{array}{l}-1.43 \\
(1.10)\end{array}$ \\
\hline fdiroy & - & - & - & $\begin{array}{l}0.002 \\
(0.02)\end{array}$ \\
\hline Size & $\begin{array}{l}0.0001^{\star *} \\
(0.00008)\end{array}$ & $\begin{array}{c}0.0002 \\
(0.00008)\end{array}$ & $\begin{array}{l}0.0001^{* *} \\
(0.00007)\end{array}$ & $\begin{array}{l}0.0002^{\star *} \\
(0.0001)\end{array}$ \\
\hline Size square & $\begin{array}{l}-3.96 e-10 \\
(7.51 e-10)\end{array}$ & $\begin{array}{c}1.36 \mathrm{e}-10 \\
(3.50 \mathrm{e}-10)\end{array}$ & $\begin{array}{l}-1.57 \mathrm{e}-10 \\
(5.03 \mathrm{e}-10)\end{array}$ & $\begin{array}{c}-2.80 \mathrm{e}-09^{\star *} \\
(1.12 \mathrm{e}-09)\end{array}$ \\
\hline Observations & 1248 & 579 & 359 & 301 \\
\hline $\mathrm{R}^{2}$ & 0.57 & 0.57 & 0.66 & 0.59 \\
\hline Time Fixed Effects & YES & YES & YES & Yes \\
\hline
\end{tabular}

Note: All the results are based on fixed effects panel data estimation. All the nominal values have been deflated by industry wise whole sale price index with the base year 2004-2005. Time fixed effects are also included. All the reported errors are robust standard errors.

presented in Column (4). The coefficients of royalty and interaction term are not significant refraining me to conclude anything from them. Thus the results reflect only one channel positively affecting wage inequality which on the job training. All other tested channels of innovation, technological change and imitation are insignificant and inconclusive.

\section{High Technology and Low Technology Sectors}

In Table 4, I present the result of high technology sectors and low technology sectors separately for all the channels through. High technology sectors include chemicals, metal, machinery and transport equipment and low technology sectors include textile, food, consumer goods, and construction. Column shows the effects for the channel of on the job training. I find that only the interaction term 
Table 4. Effect of FDI on relative wages (high skilled and low skilled industries).

\begin{tabular}{|c|c|c|c|c|c|c|c|c|}
\hline \multirow[t]{2}{*}{ Explanatory vars } & \multicolumn{4}{|c|}{$\begin{array}{c}\text { High tech industries } \\
\text { (Chemicals, Metal, Machinery and transport equipment) }\end{array}$} & \multicolumn{4}{|c|}{$\begin{array}{c}\text { Low tech industries } \\
\text { (Textile, Food, Consumer goods, Construction) }\end{array}$} \\
\hline & 1 & 2 & 3 & 4 & 5 & 6 & 7 & 8 \\
\hline Foreign shares & $\begin{array}{c}-0.0004 \\
(0.007)\end{array}$ & $\begin{array}{l}-0.01 \\
(0.009)\end{array}$ & $\begin{array}{c}0.02 \\
(0.03)\end{array}$ & $\begin{array}{l}-0.004 \\
(0.008)\end{array}$ & $\begin{array}{l}0.01^{* *} \\
(0.006)\end{array}$ & $\begin{array}{l}-0.002 \\
(0.006)\end{array}$ & $\begin{array}{l}-0.01 \\
(0.02)\end{array}$ & $\begin{array}{l}-0.18 \\
(0.11)\end{array}$ \\
\hline $\begin{array}{l}\text { Openness } \\
\text { training }\end{array}$ & $\begin{array}{c}0.0008^{\star * *} \\
(0.0002) \\
1.52 \\
(1.66)\end{array}$ & $\begin{array}{c}0.0007^{\star * *} \\
(0.0001) \\
-\end{array}$ & $\begin{array}{c}0.0009^{* * *} \\
(0.0002) \\
-\end{array}$ & $\begin{array}{c}0.02 \\
(0.01) \\
-\end{array}$ & $\begin{array}{c}-0.0001^{* * *} \\
(0.00002) \\
48.78^{*} \\
(38.08)\end{array}$ & $\begin{array}{c}-0.0001 \\
(0.0003) \\
-\end{array}$ & $\begin{array}{c}-0.0003^{\star} \\
(0.0002) \\
-\end{array}$ & $\begin{array}{c}-0.0003^{\star * *} \\
(0.00006) \\
-\end{array}$ \\
\hline fditrain & $\begin{array}{l}0.0001^{\star * *} \\
(0.00007)\end{array}$ & - & - & - & $\begin{array}{c}-0.0009^{* * *} \\
(0.0001)\end{array}$ & - & - & - \\
\hline $\mathrm{RnD}$ & - & $\begin{array}{l}-13.62 \\
(11.85)\end{array}$ & - & - & - & $\begin{array}{l}-14.64 \\
(21.69)\end{array}$ & - & - \\
\hline fdirnd & - & $\begin{array}{c}0.23 \\
(0.25)\end{array}$ & - & - & - & $\begin{array}{c}0.72 \\
(1.45)\end{array}$ & - & - \\
\hline $\mathrm{kl}$ & - & - & $\begin{array}{c}-0.0008 \\
(0.002)\end{array}$ & - & - & - & $\begin{array}{l}-0.004 \\
(0.003)\end{array}$ & - \\
\hline fdikl & - & - & $\begin{array}{l}-0.00006 \\
(0.00005)\end{array}$ & - & - & - & $\begin{array}{c}0.00007 \\
(0.00006)\end{array}$ & - \\
\hline roy & - & - & - & $\begin{array}{l}-1.30 \\
(0.82)\end{array}$ & - & - & - & $\begin{array}{l}-77.01 \\
(58.88)\end{array}$ \\
\hline fdiroy & - & - & - & $\begin{array}{c}0.006 \\
(0.001)\end{array}$ & - & - & - & $\begin{array}{c}0.74 \\
(1.15)\end{array}$ \\
\hline Size & $\begin{array}{c}0.0007 \\
(0.0009)\end{array}$ & $\begin{array}{l}0.0002^{\star *} \\
(0.00007)\end{array}$ & $\begin{array}{l}0.0001^{\star *} \\
(0.0001)\end{array}$ & $\begin{array}{l}0.0003^{\star *} \\
(0.0001)\end{array}$ & $\begin{array}{l}0.0005^{\star * *} \\
(0.0001)\end{array}$ & $\begin{array}{l}0.0007^{\star} \\
(0.0004)\end{array}$ & $\begin{array}{l}0.0006^{*} \\
(0.0004)\end{array}$ & $\begin{array}{l}0.0007^{\star *} \\
(0.0001)\end{array}$ \\
\hline Size square & $\begin{array}{l}-1.14 \mathrm{e}-11 \\
(6.14 \mathrm{e}-10)\end{array}$ & $\begin{array}{c}2.99 \mathrm{e}-10 \\
(3.65 \mathrm{e}-10)\end{array}$ & $\begin{array}{l}-2.62 \mathrm{e}-10 \\
(6.49 \mathrm{e}-10)\end{array}$ & $\begin{array}{c}-2.42 \mathrm{e}-09^{\star *} \\
(9.20 \mathrm{e}-10)\end{array}$ & $\begin{array}{c}-6.94 \mathrm{e}-09^{\star *} \\
(2.58 \mathrm{e}-09)\end{array}$ & $\begin{array}{c}-2.75 e-08^{*} \\
(1.50 e-08)\end{array}$ & $\begin{array}{c}-9.65 e-09^{*} \\
(6.09 e-09)\end{array}$ & $\begin{array}{c}-1.44 \mathrm{e}-08^{\star *} \\
(3.55 \mathrm{e}-09)\end{array}$ \\
\hline Observations & 934 & 439 & 266 & 230 & 314 & 140 & 93 & 71 \\
\hline $\mathrm{R}^{2}$ & 0.69 & 0.56 & 0.70 & 0.65 & 0.48 & 0.61 & 0.58 & 0.18 \\
\hline Fixed Effects & Yes & Yes & Yes & Yes & Yes & Yes & Yes & Yes \\
\hline
\end{tabular}

Note: All the results are based on fixed effects panel data estimation. All the nominal values have been deflated by industry wise whole sale price index with the base year 2004-2005. All the reported errors are robust standard errors.

of foreign share and training is positive and highly significant in line with the previous results suggesting a positive effect of training by foreign firms on wage inequality. Openness is found to be significant and positively related to wage inequality. All the other channels of innovation, technological changes and imitation effects are insignificant (Column 2 - 4). Column (5) shows the result of training on wages inequality for low technology sectors. The coefficient of interaction term of foreign shares and training becomes negative whereas the foreign share and training itself are positive and significantly related to wage inequality. Openness also becomes negative and significant now. The possible reasons for this contradictory result may be something specific to the low technology sectors. Foreign share itself is positive but the training channel effect is negative. All the other channels are insignificant and ineffective to wage inequality.

As another robustness check I check for the age wise heterogeneity in the 
training channel effects on wage inequality. Table 5 shows the results for firms belonging to different age groups. Column (1) presents the results for the firms belonging to age group of oldest firms which are more than 65 years of age. Only the coefficient of foreign share and training is significant and negative. All the other variables are insignificant. In the case of firm from 65 - 44 year's age group I do not find any significant result. Whereas the firms belonging to 43 - 30, 2 25 and less than 24 years all have a positive and significant effect of interaction term of foreign shares and training on wages inequality. The reason behind this result could be that the new firms may be lacking in resources to training the employees but still they add to the demand for skills in the labour market. On the other hand the old firms are established and equipped with resources to spend on training and help the human capital formation in labour market.

\section{Conclusion}

This paper attempted to assess the effects of foreign direct investment on wage inequality through different channels in Indian manufacturing sector for the period 2001-2015. Labor mobility, innovation, technological changes and imitation are the channels which I used to see this effect. The results indicate positive effect of on the job training by foreign firms on wage inequality. I find that specifically this channel has strong effects in creating the wage inequality in manufacturing sector in India. All the other channels like innovation, imitation and technological changes are found to be insignificant. The results also suggest the existence of this effect particularly for the high technology sectors. Openness of

Table 5. Age-wise effect of FDI on relative wages and human capital.

\begin{tabular}{cccccc}
\hline Explanatory vars & $\begin{array}{c}>65 \text { years } \\
(1)\end{array}$ & $\begin{array}{c}65-44 \text { years } \\
(2)\end{array}$ & $\begin{array}{c}43-30 \text { years } \\
(3)\end{array}$ & $\begin{array}{c}29-25 \text { years } \\
(4)\end{array}$ & $\begin{array}{c}<4 \\
(5)\end{array}$ \\
\hline \multirow{2}{*}{ Foreign shares } & 0.003 & -0.003 & 0.007 & 0.002 & -0.003 \\
& $(0.003)$ & $(0.009)$ & $(0.006)$ & $(0.001)$ & $(0.01)$ \\
Openness & -0.0001 & 0.00006 & $1.84 \mathrm{e}-07$ & $0.002^{* * *}$ & $0.0004^{* * *}$ \\
& $(0.0001)$ & $(0.0001)$ & $(0.00004)$ & $(0.0001)$ & $(0.0001)$ \\
training & 46.16 & 281.02 & $0.0009^{* * *}$ & 0.27 & $32.44^{* *}$ \\
& $(32.59)$ & $(101.9)$ & $(0.00001)$ & $(0.52)$ & $(16.9)$ \\
Fditrain & $-0.0007^{* *}$ & -0.0008 & $0.0003^{* * *}$ & $0.0001^{* * *}$ & $0.0009^{* * *}$ \\
& $(0.0003)$ & $(0.0006)$ & $(0.00008)$ & $(0.0002)$ & $(0.0003)$ \\
Size & 0.0002 & $0.0007^{*}$ & $0.0001^{*}$ & 0.00004 & $0.0002^{* *}$ \\
& $(0.0002)$ & $(0.0003)$ & $(0.00005)$ & $(0.0001)$ & $(0.0001)$ \\
Size square & $-9.60 \mathrm{e}-10^{*}$ & $-1.12 \mathrm{e}-08^{*}$ & $-1.91 \mathrm{e}-09^{*}$ & $-3.04 \mathrm{e}-10$ & $-1.12 \mathrm{e}-08^{* *}$ \\
& $(3.61 \mathrm{e}-10)$ & $(4.76 \mathrm{e}-09)$ & $(9.90 \mathrm{e}-10)$ & $(9.52 \mathrm{e}-10)$ & $(4.76 \mathrm{e}-09)$ \\
Observations & 249 & 137 & 261 & 427 & 174 \\
$\mathrm{R}^{2}$ & 0.53 & 0.71 & 0.53 & 0.69 & 0.44 \\
Fixed Effects & Yes & Yes & Yes & Yes & Yes \\
\hline
\end{tabular}

Note: All the results are based on fixed effects panel data estimation. All the nominal values have been deflated by industry wise whole sale price index with the base year 2004-2005. All the reported errors are robust standard errors. 
the firms is also a positive and significant factor contributing to wage inequality. The newer firms specifically show the positive effect on wage inequality. The studies have tried to see effect of foreign direct investment and trade and wage inequality confirm to our results with positive effect on wage inequality. [30] find that big foreign firms have higher technological spill overs on domestic firms for Greek firms. [31] find cross country evidence of increasing skilled and unskilled wage gap for developing countries. [19] has found positive effect of skill biased technological change and wage inequality in Indian manufacturing sector caused by changing nature of production. Similarly [22] find positive effect of FDI on wage inequality in India and propose skill biased technological change as the channel of this effect. But none of these studies talks about the channel of on the job training in assessing the effect of foreign direct investment on wage inequality which has been showed in this paper. There have been studies which estimated the productivity spill overs from FDI but they also focus on the innovation channel to assess the productivity effects from FDI. Thus this paper proposes a new and strong channel which could explain positive wage inequality. The paper can be further extended to other sectors like services and explore the various heterogeneities at different levels like entity, ownership etc. Further the limitation of the paper is that it ignores the possible endogeneity in FDI and human capital. Thus future research can be extended to the dynamic estimation techniques or instrumental variable techniques.

\section{Acknowledgements}

The author acknowledges the insightful discussions with Professor Sugata Marjit, Dr. Pranab Kumar Das, Professor Saibal Kar and the participants in the conferences.

\section{References}

[1] Balasubramanyam, V.N., Salisu, M. and Sapsford, D. (1999) Foreign Direct Investment as an Engine of Growth. The Journal of International Trade \& Economic Development, 8, 27-40. https://doi.org/10.1080/09638199900000003

[2] Kathuria, V. (2002) Liberalisation, FDI, and Productivity Spillovers-An Analysis of Indian Manufacturing Firms. Oxford Economic Papers, 54, 688-718.

[3] Blomström, M., Kokko, A. and Zejan, M. (1994) Host Country Competition, Labor Skills, and Technology Transfer by Multinationals. Review of World Economics (Weltwirtschaftliches Archiv), 130, 521-533.

[4] Balsvik, R. and Haller, S. (2011) Foreign Firms and Host-Country Productivity: Does the Mode of Entry Matter? Oxford Economic Papers, 63, 158-186.

[5] Gersbach, H. and Schmutzler, A. (2011) Foreign Direct Investment and R\&DOffshoring. Oxford Economic Papers, 63, 134-157.

[6] Becker, G. (1993) Human Capital: A Theoretical and Empirical Analysis, with Special Reference to Education. Chicago University Press, Chicago. https://doi.org/10.7208/chicago/9780226041223.001.0001

[7] Nelson R.R. and Phelps, E.S. (1966) Investment in Humans, Technological Diffusion, and Economic Growth. American Economic Review, 56, 69-75. 
[8] Acemoglu, D. and Angrist, J. (2001) How Large Are Human-Capital Externalities? Evidence from Compulsory-Schooling Laws. NBER Chapters, NBER Macroeconomics Annual, 15, 9-74.

[9] Lipsey, E.R., Sjöholm, F. and Sun, J. (2013) Foreign Ownership and Employment Growth in a Developing Country. Journal of Development Studies, 49, 1133-1147. https://doi.org/10.1080/00220388.2013.794264

[10] Baldwin, E.R. (1994) Effects of Trade and Foreign Direct Investment on Employment and Relative Wages. OECD Economic Studies No. 23.

[11] Laixun, Z. (1998) The Impact of Foreign Direct Investment on Wages and Employment. Oxford Economic Papers, Oxford University Press, Vol. 50, 284-301.

[12] Kapstien, B.E. (2001) Virtuous Circles? Human Capital Formation, Economic Development, and the Multinational Enterprise. Paper Presented to the OECD Conference on FDI, Human Capital, and Education in Developing Countries Technical Meeting, Paris.

[13] Miyamoto, K. (2003) Human Capital Formation and Foreign Direct Investment in Developing Countries. Working Paper No. 211, OECD Development Centre.

[14] Ritchie, K.B. (2002) Foreign Direct Investment and Intellectual Capital Formation in South-East Asia. OECD Development Centre, Working Paper No. 194.

[15] Figini, P. and Görg, H. (1999) Multinational Companies and Wage Inequality in the Host Country: The Case of Ireland. Review of World Economics, 135, 594-612. https://doi.org/10.1007/BF02707386

[16] Velde, D. (2001) Foreign Direct Investment and Factor Prices in U.S. Manufacturing. Review of World Economics, 137, 622-643.

[17] Goldar, B. and Banga, R. (2007) Impact of Trade Liberalization on Foreign Direct Investment in Indian Industries. Working Papers No. 3607, Asia-Pacific Research and Training Network on Trade (ARTNeT), an Insaitiative of UNESCAP and IDRC.

[18] Nunnenkamp, P. and Rudi, S. (2007) Foreign Direct Investment in Post Reform India: Likely to Work Wonder for Regional Development? Kiel Working Paper No. 1375.

[19] Ramaswamy, K.V. (2008) Wage Inequality in Indian Manufacturing-Is It Trade, Technology or Labour Regulations? Labor Economics Working Papers 22361, East Asian Bureau of Economic Research.

[20] Katz, L.F. and Murphy, K.M. (1992) Changes in Relative Wages, 1963-1987: Supply and Demand Factors. The Quarterly Journal of Economics, 107, 35-78.

[21] Dirk Te, V. and Oliver, M. (2004) Foreign Direct Investment, Skills and Wage Inequality in East Asia. Journal of the Asia Pacific Economy, 9, 348-369.

[22] Banga, R. (2007) Liberalisation and Wage Inequality in India. Working Papers ID 805 , eSocial Sciences.

[23] Mincer, J. (1991) Human Capital, Technology, and the Wage Structure: What do the Time Series Show? NBER Working Paper No. 3581.

[24] Hanel, P. (2000) R\&D, Interindustry and International Technology Spillovers and the Total Factor Productivity Growth of Manufacturing Industries in Canada, 1974-1989. Economic Systems Research, 12, 345-361. https://doi.org/10.1080/09535310050120925

[25] Schafer, J. (2005) Missing Data in Longitudinal Studies: A Review. Department of Statistics and the Methodology Centre, The Pennsylvania State University. 
[26] Cameron, C.A. and Trivedi, K.P. (2005) Microeconometrics Methods and Applications. Cambridge University Press. https://doi.org/10.1017/CBO9780511811241

[27] Kumar, N. and Siddharthan, N.S. (1994) Technology, Firm Size and Export Behaviour in Developing Countries: The Case of Indian Enterprises. Journal of Develop ment Studies, 31, 289-309. https://doi.org/10.1080/00220389408422362

[28] Parameswaran, M. (2009) International Trade, R\&D Spillovers and Productivity: Evidence from Indian Manufacturing Industry. Journal of Development Studies, 45, 1249-1266.

[29] Sahu, P. (2010) FDI, Wage Inequality and Employment in Emerging Economies: Recent Evidence from Indian Manufacturing. MPRA Paper.

[30] Dimelis, S. and Louri, H. (2004) Foreign Direct Investment and Technology Spillovers: Which Firms Really Benefit? Review of World Economics, 140, 230-253.

[31] Gopinath, M. and Chen, W. (2003) Foreign Direct Investment and Wages: A Cross-Country Analysis. The Journal of International Trade \& Economic Development, 12, 285-309. https://doi.org/10.1080/0963819032000132067

[32] Baranwal, G. (2016) Does Foreign Direct Investment Form Human Capital? A Study with World Input-Output Data in India. In: Chakraborty, D. and Mukherjee, J., Eds., Trade, Investment and Economic Development in Asia: Empirical and Policy Issues, Routledge, London, Chapter 9, 161-174.

\section{Appendix}

\begin{tabular}{|c|c|c|c|c|}
\hline Variable & Mean & Std. Dev. & Min & $\operatorname{Max}$ \\
\hline Relative wages & 1.61 & 5.36 & 0.00 & 76.56 \\
\hline Foreign share & 26.12 & 26.11 & 0.00 & 96.80 \\
\hline training & 0.03 & 1.02 & 0.00 & 51.00 \\
\hline fditrain & 901.17 & 4290.44 & 0.00 & $67,681.75$ \\
\hline rnd & 0.01 & 0.03 & 0.00 & 0.45 \\
\hline fdirnd & 0.24 & 0.98 & 0.00 & 18.00 \\
\hline $\mathbf{k l}$ & 334.61 & 189.93 & 1.00 & 663.00 \\
\hline fdikl & 8475.35 & $11,067.63$ & 0.00 & $53,969.94$ \\
\hline droy & 0.02 & 0.19 & 0.00 & 4.62 \\
\hline fdiroy & 0.86 & 10.26 & 0.00 & 250.26 \\
\hline open & 1740.87 & $11,001.74$ & 0.00 & $397,421.10$ \\
\hline size & 4749.67 & $25,584.40$ & 0.00 & $776,324.10$ \\
\hline size sq & $677,000,000.00$ & $13,200,000,000.00$ & 0.00 & $603,000,000,000.00$ \\
\hline
\end{tabular}

